\title{
ANALISIS PERBANDINGAN AVERAGE ABNORMAL RETURN DAN AVERAGE TRADING VOLUME ACTIVITY SEBELUM DAN SETELAH PEMILIHAN LEGISLATIF DAN PEMILIHAN PRESIDEN TAHUN 2019
}

\author{
Muhajir**1, Nita Erika Ariani*2 $^{* 2}$ \\ ${ }^{1,2}$ Program Studi Akuntansi Fakultas Ekonomi dan Bisnis Universitas Syiah Kuala \\ e-mail: muhajirpaloh@gmail.com ${ }^{* 1}$, nea@unsyiah.ac.id ${ }^{* 2}$
}

\begin{abstract}
This study aims to analyzed the diffirences in average abnormal pengmbalians and average trade volume activity before and after the 2019 legislative and presidential election.The result shows that: (1) Base on the results of the test of the average abnormal pengmbalian while the event periode, the average abnormal pengmbalian before and after the 2019 legislative and presidential election. (2) From the results of the test of the average trading volume activity before and after 2019 legislative and presidential election es shows that there are statistically different average trading volume activity before and after 2019 legislative and presidential election. Based on the results, the issuers are advisable to improve the fundamental quality of the company. Investors are recommended to improve their competence in interpreting information related to stock prices as good news or bad news. For further research, it is recommended to expand research sample and the observation period
\end{abstract}

Keywords: average abnormal pengmbalian, average trading volume activit, event study,political event.

\section{Pendahuluan}

Investor merupakan pihak yang paling penting dan menentukan dalam target modal. Investor sebagai penyedia modal kaitan kekuasaan dalam memutuskan apakah akan melakukan investasi atau. Investor sangat memahami bahwa informasi yang terkandung dari kejadian-kejadian tertentu kaitan dampak terhadap kinerja saham, sehingga investor menghadapi ketidakpastian terhadap kinerja saham mereka pada aktivitas kejadian tersebut alami (Jones, 2007:434 dalam Ary Gumanti, 2011:297).

Menurut Samsul (2015:226), suatu kejadian yang bernilai berdampak sikap investor terhadap aktivitas investasi di bursa efek. Sikap investor di bursa efek dalam bentuk melakukan reaksi secara cepat terhadap informasi bernilai yang datang dari dalam dan dari luar bursa efek dapat diartikan bahwa bursa efek tersebut telah efisien.

Menurut Samsul (2015:9-10), kejadian politik kaitan hubungan yang kuat dengan pertumbuhan target modal di Indonesia. Kejadian politik mampu menciptakan ketidakpastian di bursa efek dan situasi yang tidak pasti ini sangat tidak menguntungkan bagi investor. pemilihan kepala daerah (pilkada), demonstrasi dan pengesahan Undang-Undang baru dapat mempengaruhi reaksi investor di bursa efek yang pada akhirnya berdampak terhadap kenaikan (Samsul, 2015:228).

Menurut Roihana (2007:19) dalam Samsul (2015:10), salah satu variabel yang mempengaruhi reaksi pelaku target di bursa efek yakni pemilu (pemilihan umum). Pemilu yakni kejadian besar bagi suatu negara. Pemilu dapat memproyeksikan bagaimana kinerja ekonomi ketika pemerintahan baru dijalankan. Investor dapat menderita keuntungan atau kerugian investasi karena perubahan kebijakan politik suatu negara. Selama pemilu, target saham akan menjadi tidak stabil karena pelaku target menganggap berita yang diraih dapat dijadikan penilaian apakah pelaku target akan mendapatkan manfaat dari calon presiden yang berpotensi memenangkan pemilu.

Pemilihan legslatif dan eksektif sebagai dua komponen utama dalam pelaksanaan pemilu merupakan kejadian yang mengawali perubahan yang alami pada lembaga legislatif dan lembaga eksekutif. Pileg dan pilpres menentukan siapa wakil rakyat dan kepala pemerintahan yang dalam lima tahun kedepan akan merumuskan dan menetapkan kebijakankebijakan nasional yang mempengaruhi hajat hidup warga negara, termasuk di dalamnya kebijakan ekonomi. 
Presiden berkaitan kekuasaan yang sangat besar dalam menentukan arah pembangunan nasional. Program kerja, prioritas pembangunan dan kebijakan yang diambil oleh presiden kaitan dampak secara langsung terhadap pertumbuhan satu atau beberapa sektor di bursa efek. Oleh karena itu, reaksi bursa efek terhadap kejadian ini tentunya menjadi sesuatu yang menarik untuk dipelajari guna mengantisipasi kejadian.

Rabu tanggal 17 April 2019 berdasarkan jadwal resmi KPU RI, rakyat Indonesia telah menggunakan hak politiknya melalui pemilihan umum. Sesuai dengan yang diberitakan oleh RRI (Radio Republik Indonesia) online, pileg dan pilpres tahun 2019 diikuti oleh 16 Partai Nasional. Pemilu yang digelar pada 17 April 2019 merupakan pemilu terbesar sepanjang sejarah Indonesia. Pasalnya, pada pemilu tahun ini masyarakat memilih kandidat legislatif dan eksekutif baru(RRI online, 2019).

Investor di target modal sebagai bagian dari masyarakat tentu memberikan perhatian serius terhadap kejadian pileg dan pilpres ini, pertama yakni karena alasan pemenuhan hak demokrasi dirinya dan yang kedua yakni karena berkenaan dengan prospek investasi yang telah ditanamkan di target modal. Oleh karena itu, dinamika yang alami dalam eskalasi politik nasional pra-pemilu dan pasca-pemilu menjadi sesuatu yang menarik untuk diteliti guna mengetahui dampak perubahan politik pada berbagai sektor kehidupan bernegara, khususnya investasi di bursa efek.

Perdagangan saham merespon positif pesta demokrasi pileg dan pilpres tahun 2019. Sesuai dengan yang diberitakan oleh Jawa Pos, sekretaris perusahaan nilai kapitalisasi target sepanjang pileg dan pilpres 2019 meningkat sebesar 1,58 persen. BEI mencatat nilai kapitalisasi target alami peningkatan pada pekan sebelum pemilu. Hal ini teralat dengan Indeks Nilai Saham Gabungan (IHSG) yang juga alami peningkatan (Jawa Pos, 2019).

Berdasarkan nilai IHSG di sekitar kejadian pileg dan pilpres 2019, terdapat satu hal yang menarik untuk diteliti yaitu adanya peningkatan nilai IHSG pada aktivitas sebelum kejadian pileg dan pilpres dan alami kenaikan nilai IHSG sesudah pileg dan pilpres seperti yang digambarkan pada Tabel 1.1 berikut:

Tabel 1.1

Perubahan Nilai IHSG (12-23 April 2019)

\begin{tabular}{|c|c|c|}
\hline Tanggal & IHSG & Poin \\
\hline 12 April 2019 & $6,405.87$ & -4.30 \\
\hline 15 April 2019 & $6,435.15$ & 29.29 \\
\hline 16 April 2019 & $6,481.54$ & 46.39 \\
\hline 18 April 2019 & $6,507.22$ & 25.68 \\
\hline 22 April 2019 & $6,414.74$ & -92.48 \\
\hline 23 April 2019 & $6,462.82$ & 48.08 \\
\hline
\end{tabular}

Sumber: IDX (2019)

Berdasarkan tabeldiatas "HSG" naikselama 3 hari berturut-turut sebelum pileg dan pilpres tanggal 17 April 2019, yaitu pada tanggal 12-16 April 2019 alami peningkatan sebesar 75.67 poin menjadi 6,481.54. Sedangkan 3 hari sesudah pileg dan pilpres menunjukkan bahwa IHSG bergerak cukup fluktuatif, yaitu pada tanggal 18 April 2019 alami kenaikan sebesar 25,68 poin menjadi $6,507.22$, kemudian alami penurunan sebesar 92,47 poin pada tanggal 22 April 2019 menjadi 6,414.74 dan alami kenaikan sebesar 48,07 poin menjadi 6,462.82 tanggal 23 April 2019.

\section{Kerangka Teoritis dan Pengembangan Hipotesis Saham}

Saham yakni sebagai alat penyertaan atau kepunyaan personal maupun entitas dalam perusahaan. Bagian dari kepunyaan berdasarkan yang tertanam (Ary Gumanti, 2011:31). Nilai saham yakni nilai per lembar saham pada aktivitas tertentu yang berlaku di target modal. Nilai saham alami kenaikan dari waktu ke waktu, baik berupa kenaikan maupun penurunan (Martalena \& Malinda, 2011:14). 


\section{Pengmbalian Saham}

Menurut Jogiyanto (2015:63-64), pengmbalian saham yakni akhir hasil terhadap yang diraih . Pengmbalian saham terbagi lagi menjadi dua macam, yaitu actual pengmbalian dan expected pengmbalian. Actual pengmbalian merupakan pengmbalian yang telah alami. Actual pengmbalian dapat diformulasikan sebagai berikut (Jogiyanto, 2015:64):

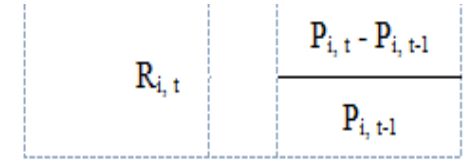

\section{Keterangan:}

$\mathrm{R}_{\mathrm{j}, \mathrm{t}} \quad$ : retum saham i pada hari $\mathrm{t}$

$\mathrm{P}_{\mathrm{i}, \mathrm{t}} \quad$ : harga saham i pada hari $\mathrm{t}$

$\mathrm{P}_{\mathrm{i}, \mathrm{t}-\mathrm{1}} \quad$ : harga saham i pada hari sebelumnya (t-1)

Jogiyanto (2015:73-79) adanya 3 bentuk statistikal dalam memperkirakan expected pengmbalian, yaitu sebagai berikut:

\section{1) Mean-adjusted Model}

Model average (mean-adjusted model) kaitan pandangan yakni ekspektasi nantinya akan mendapatkan hasil nilai sama dengan pengmbalian actual.

\section{2) Market-adjusted Model}

Model target (market-adjusted model) yakni indeks target untuk menentukan expected pengmbalian suatu saham, sehingga tidak perlu menggunakan perkiraan waktu.

3) Market Model

Market model sering juga disebut sebagai model indeks tunggal karena menggunakan indeks yaitu indeks pasar.

\section{Abnormal Pengmbalian}

Jogiyanto (2015:69), abnormal pengmbalian merupakan selisih atau hasil pengurangan dari actual pengmbalian terhadap expected pengmbalian. Berikut ini rumus abnormal pengmbalian (Jogiyanto, 2015:94):

$$
A R_{i, t}=R_{i, t}-E\left(R_{i, t}\right)
$$

Keterangan:

$\mathrm{AR}_{\mathrm{i}, \mathrm{t}}$ : abnormal return saham i pada periode ke-t

$\mathrm{R}_{\mathrm{i}, \mathrm{t}}$ : actual return saham i pada periode ke $\mathrm{t}$

\section{Trading Volume Activity}

Menurut Budiman (2009), trading volume activity yakni indikator dengan banyaknya peminat investor pada saham tertentu. Artinya, jika besar tingkat volume perdagangan suatu saham maka semakin tinggi minat investor untuk mendapatkan saham tersebut, begitu juga sebaliknya

\section{Efficient Market Hyphothesis}

Menurut Fama (1970) dalam Ary Gumanti (2011:326) mengatakan bahwa target yang efisien yakni target dimana seorang investor secara cepat dapat mengekspektasi nilai suatu sekuritas cukup dengan menggunakan informasi yang tersedia di bursa efek, sehingga semakin cepat suatu informasi direspon oleh target maka semakin efisien target tersebut.

\section{Perbandingan Average Abnormal pengmbalian} Sebelum dan Sesudah Pemilihan Legislatif dan Pemilihan Presiden Tahun 2019

Abnormal pengmbalian yang alami pada Bursa Efek Indonesia mungkin saja alami akibat munculnya informasi lain bukan karena disebabkan oleh kejadian pileg dan pilpres tahun 2019 yang menjadi titik pengamatan. Signifikansi abnormal pengmbalian pada Bursa Efek Indonesia harus diuji apakah merupakan hasil reaksi dari kejadian pileg dan pilpres tahun 2019 yang menjadi titik pengamatan ataukah hasil reaksi dari kejadian lain.

\section{Perbandingan Average Trading Volume Activity Sebelum dan Sesudah Pemilihan Legislatif dan Pemilihan Presiden Tahun 2019}

Trading volume activity digunakan untuk menganalisis sinyal positif dari kejadian pileg dan pilpres tahun 2019 yang diterima oleh investor dalam membuat keputusan perdagangan saham di bursa efek. Jika investor menganggap kejadian pileg dan pilpres tahun 2019 sebagai sinyal positif, maka hal tersebut akan memperbesar tingkat volume.

Berdasarkan rumusan dan permasalahan yang telah diuraikan sebelumnya, maka skema kerangka pemikiran studi ini diilustrasikan dalam Gambar 2.1. 


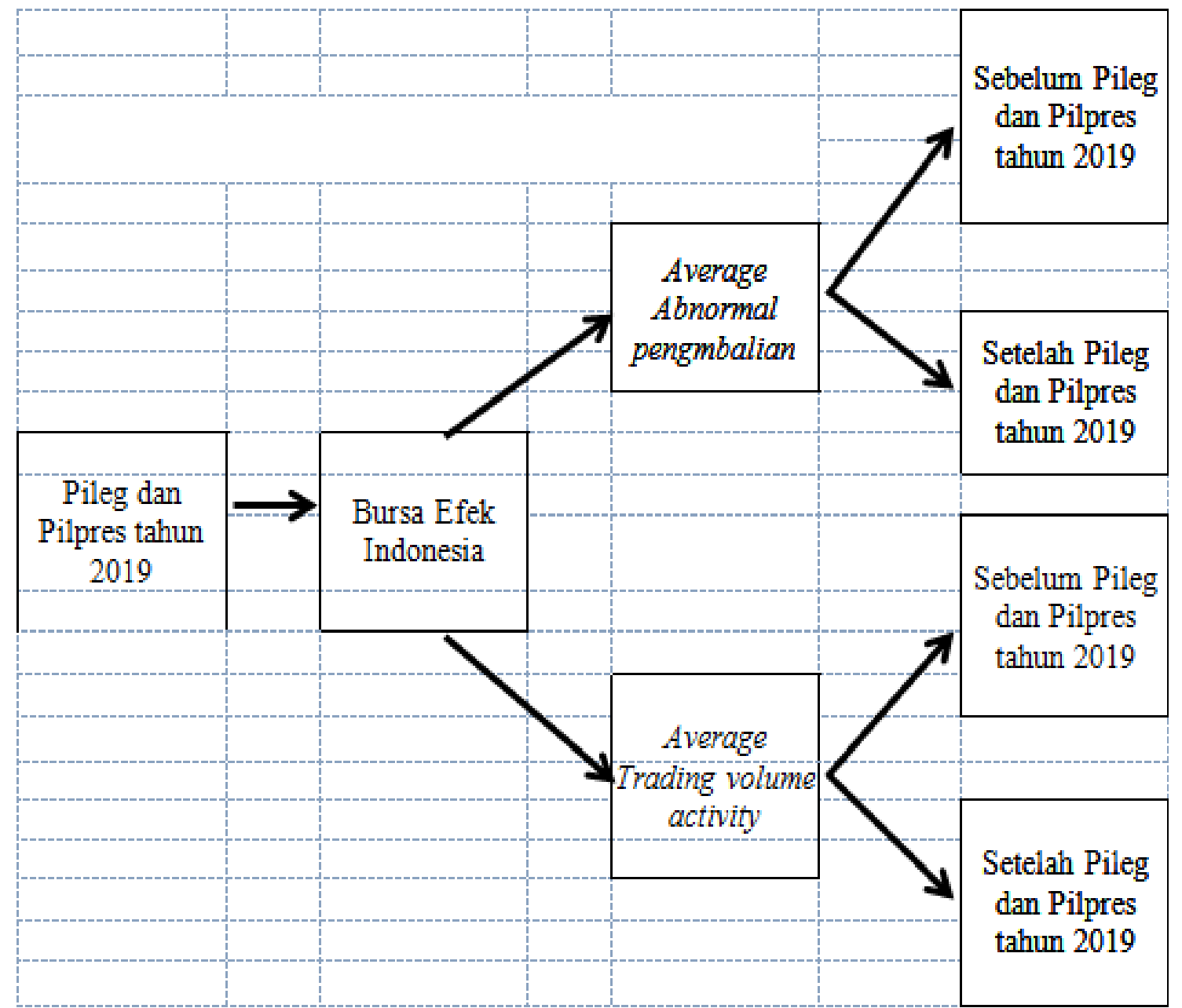

Gambar 2.1 Bagan Kerangka Pemikiran

\section{Metode Penelitian}

\section{Sample dan Sumber Data}

Popuasi penelitian ini yakni seluruh saham perusahaan termasuk dalam indeks LQ-45 di Bursa Efek, teknik pengambilan sampel yang digunakan yakni sensus.

Data penelitian yakni data sekunder berupa data harian nilai saham dan volume perdagangan saham indeks LQ-45 pada periode pengamatan tanggal 10 April 2019 s/d tanggal 25 April 2019. Data tersebut didapatkan dengan mengunduh dari situs BEI.

\section{Operasionalisasi Varibel}

\section{Average Abnormal Pengmbalian}

Average abnormal pengmbalian sebelum/sesudah kejadian digunakan untuk menggambarkan perubahan abnormal pengmbalian saham antara sebelum dan sesudah kejadian pileg dan pilpres tahun 2019 sebagai akibat adanya kejadian tersebut. 


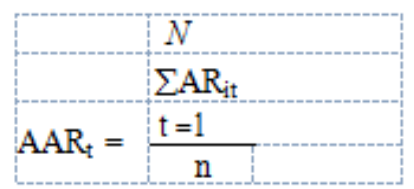

Keterangan:

$\mathrm{AAR}_{\text {nt }}$ : rata-rata abnormal retum saham pada hari t

$\sum \mathrm{AR}_{\mathrm{it}}$ : jumlah abnormal return saham i pada

hari t

n : jumlah perusahaan yang diteliti

\section{Average Trading Volume Activity}

Menurut Jogiyanto (2015:102), average trading volume activity (ATVA) yakni pengembalian dari keseluruhan saham. Average trading volume activity dapat dihitung dengan rumus sebagai berikut:

$$
\text { XTVAt }=\frac{\begin{array}{c}
i k \\
i \rrbracket \\
\frac{1}{\text { TVAt }}
\end{array}}{n}
$$

\section{Metode Analisis dan Rancangan Pengujian}

\section{Hipotesis}

Uji normalitas dipakai untuk uji t dengan menganalisis cara statistik digunakan sebagai syarat untuk dilakukan uji t .

1) Jika nilai Sig. (2-tailed) $<0,05$ maka $\mathrm{H} 0$ ditolak dan Ha diterima.

2) Sebaliknya, jika nilai Sig. (2-tailed) > 0,05 maka H0 diterima dan Ha ditolak.

\section{Hasil Dan Pembahasan}

\section{Uji Statistik Deskriptif}

Statistik Deskriptif Average Abnormal Pengmbalian

Tabel 4.1
\begin{tabular}{|l|c|c|r|r|c|}
\hline & Statistik Deskriptif Average Abnormal Return \\
\hline & N & Minimum & Maximum & Mean & Std. Deviation \\
\hline AAR_SEBELUM & 45 & -.0193 & .0184 & .000580 & .0090572 \\
\hline AAR_SETELAH & 45 & -.0299 & 1.0010 & .023402 & .1493787 \\
\hline Valid N (listwise) & 45 & & & & \\
\hline
\end{tabular}

Sumber: Output SPSS (2019)

Dari statistik deskriptif tersebut, dapat dibuat grafik seperti tampak pada Gambar 4.1.. 


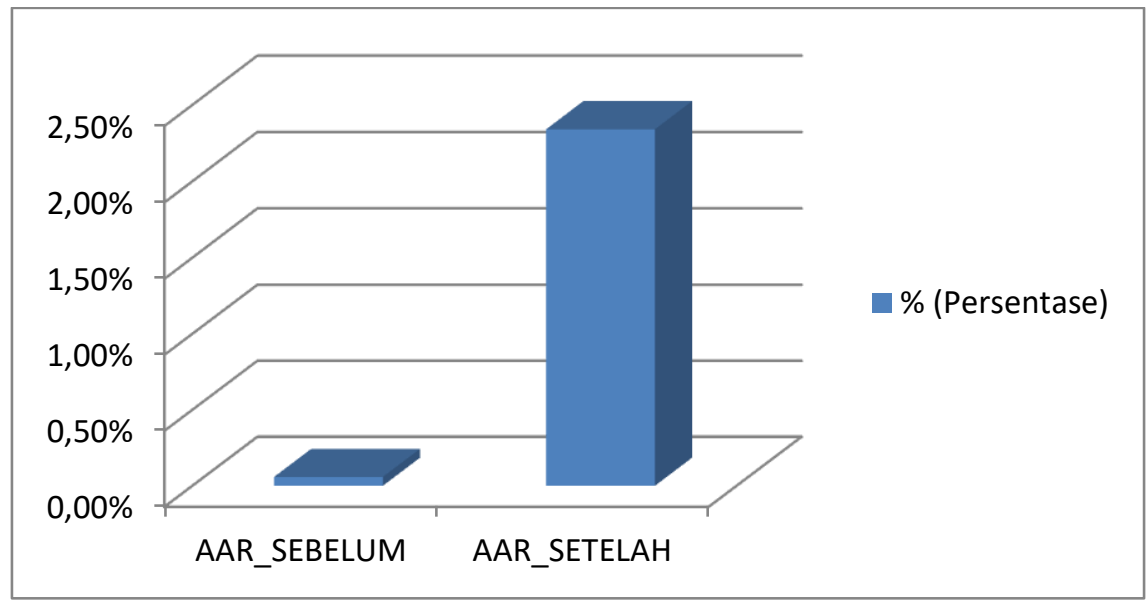

Gambar 4.1

Average Abnormal Pengmbalian Sebelum dan Pileg dan Sesudah Pilpres 2019

\section{Statistik Deskriptif Average Trading Volume Activity}

Tabel 4.2

Statistik Deskriptif Variabel Average Trading Volume Activity

\begin{tabular}{|l|c|c|c|c|c|}
\hline & $\mathrm{N}$ & Minimum & Maximum & Mean & Std. Deviation \\
\hline ATVA_SEBELUM & 45 & .0002 & .0110 & .001807 & .0020505 \\
\hline ATVA_SETELAH & 45 & .0002 & .0111 & .002271 & .0026259 \\
\hline Valid N (listwise) & 45 & & & & \\
\hline
\end{tabular}

Sumber: Output SPSS (2019)

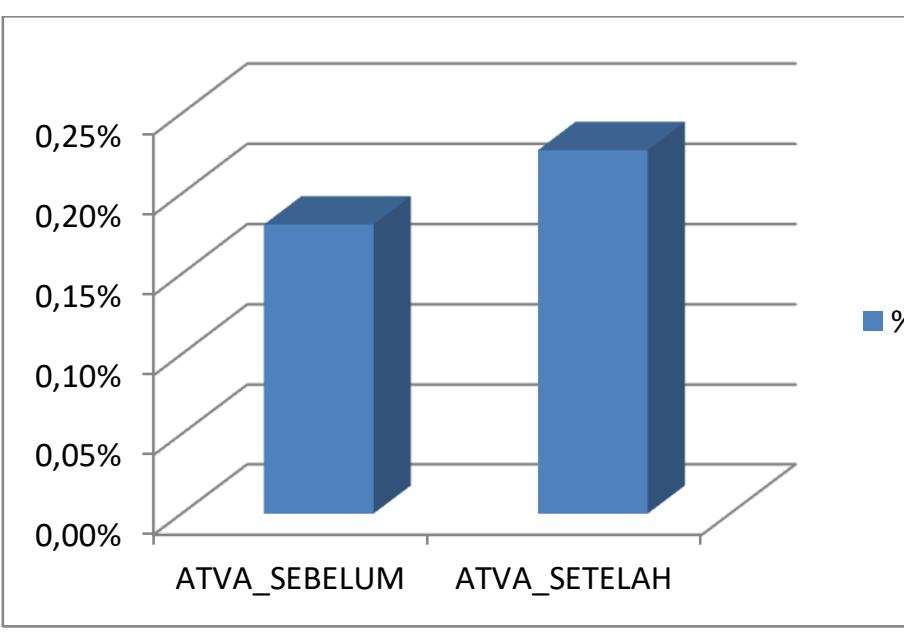

Sumber: Data diolah (2009)

Gambar 4.2

Average Trading Volume Activity Sebelum dan Sesudah Pileg dan Pilpres 2019

\section{Uji Asumsi Klasik}

Uji Normalitas Average Abnormal Pengmbalian

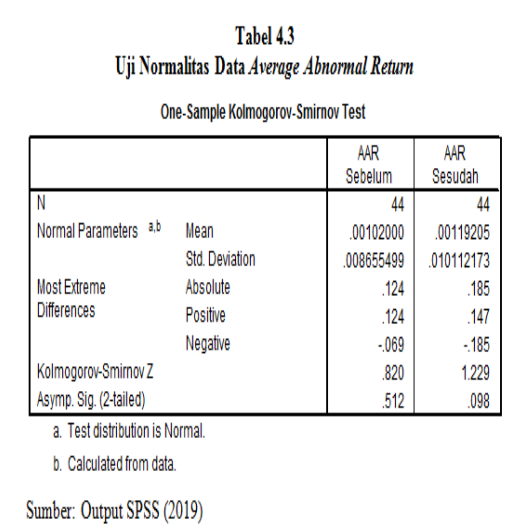

Berdasarkan uji normalitas diraih inferensi bahwa average abnormal pengmbalian (AAR) sebelum dan sesudah pileg dan pilpres 2019 kaitan data distribusi normal, maka statiktik uji t sampel ada.(paired sample t-test).

\section{Uji Normalitas Average Trading Volume Activity}


Tabel 4.4

Uji Normalitas Data Average Trading Volume Activity

One-Sample Kolmogorov-Smirnov Test

\begin{tabular}{|ll|r|r|}
\hline & & \multicolumn{1}{c|}{$\begin{array}{c}\text { ATVA } \\
\text { Sebelum }\end{array}$} & \multicolumn{1}{c|}{$\begin{array}{c}\text { ATVA } \\
\text { Sesudah }\end{array}$} \\
\hline N & 38 & 38 \\
Normal Parameter30 & Mean & .00108947 & .00130789 \\
Most Extreme & Std. Deviation & .000759370 & .001044518 \\
Differenoes & Absolute & .178 & .214 \\
& Positive & .178 & .214 \\
Kolmogorov-Smirnov Z Negative & -.121 & -.144 \\
Asymp. Sig. (2-tailed) & 1.100 & 1.316 \\
\hline \multicolumn{2}{|l|}{ 9. Test distribution is Normal. } & .178 & .063 \\
\hline
\end{tabular}

Berdasarkan uji normalitas diraih inferensi bahwa data diatas dinyatakan untuk layak dianalisis tahap selanjutnya.

\section{Hasil Pengujian Hipotesis 1}

Adapun hasil paired sample t-test dengan menggunakan SPSS versi 23 yakni seperti tampak pada Tabel 4.5.
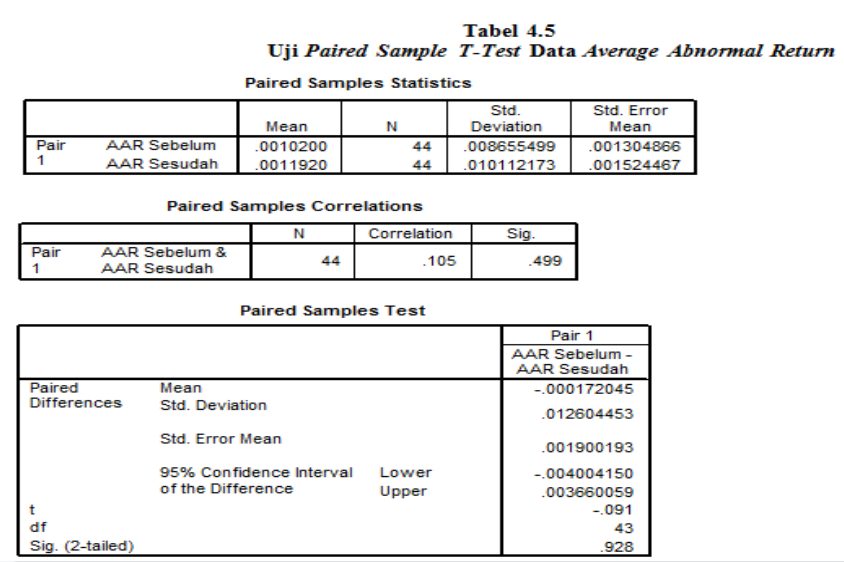

Sumber: Output SPSS (2019)

Berdasarkan tabel 4.5 diketahui nilai Sig. (2tailed) yakni sebesar 0,928 . Oleh karena sig sebesar $0,928>0,05$ maka inferensi yang diambil yakni hipotesis nol (H0) diterima dan hipotesis alternatif (Ha) ditolak. Artinya, tidak terdapat perbedaan average abnormal pengmbalian sebelum dan sesudah kejadian pileg dan pilpres 2019.

\section{Hasil Pengujian Hipotesis 2}

Adapun hasil paired sample t-test dengan menggunakan SPSS versi 23 yakni seperti tampak pada Tabel 4.6.
Tabel 4.6

Uji Paired Sample T-Test Data Average Trading Volume Activity

\begin{tabular}{|c|c|c|c|c|c|}
\hline \multicolumn{6}{|c|}{ Paired Samples Statistics } \\
\hline & & Mean & $\mathrm{N}$ & $\begin{array}{c}\text { Std. } \\
\text { Deviation }\end{array}$ & $\begin{array}{l}\text { Std. Error } \\
\text { Mean }\end{array}$ \\
\hline $\begin{array}{l}\text { Pair } \\
1\end{array}$ & $\begin{array}{l}\text { ATVA Sebelum } \\
\text { ATVA Sesudah }\end{array}$ & $\begin{array}{l}.0010895 \\
.0013079\end{array}$ & $\begin{array}{l}38 \\
38\end{array}$ & $\begin{array}{l}.000759370 \\
.001044518\end{array}$ & $\begin{array}{l}.00012319 \\
.00016944\end{array}$ \\
\hline
\end{tabular}

Paired Samples Correlations

\begin{tabular}{|ll|r|r|r|}
\hline & \multicolumn{1}{|c|}{$\mathrm{N}$} & Correlation & \multicolumn{1}{c|}{ Sig. } \\
\hline $\begin{array}{l}\text { Pair } \\
1\end{array}$ & $\begin{array}{l}\text { ATVA Sebelum \& } \\
\text { ATVA Sesudah }\end{array}$ & 38 & .871 & .000 \\
\hline
\end{tabular}

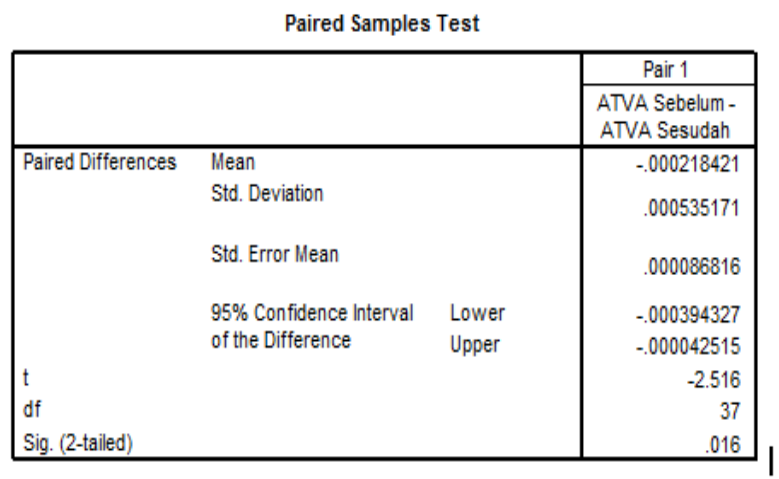

Sumber: Output SPSS (2019)

\section{Pembahasan}

Perbandingan Average Abnormal Pengmbalian Sebelum dan Sesudah Pemilihan Legislatif dan Pemilihan Presiden Tahun 2019

Hasil pertama adanya perbedaan average abnormal pengmbalian sebelum dan sesudah pileg dan pilpres 2019 yakni tidak didukung.

Dengan tidak adanya perbedaan average abnormal pengmbalian antara sebelum/sesudah kejadian dapat diartikan bahwa kejadian pileg dan pilpres 2019 tidak mengandung informasi tentang akan adanya kecenderung menunggu sampai diumumkannya hasil penghitungan suara pileg dan pilpres 2019 dan penetapan pemenang pileg dan pilpres 2019 oleh KPU.

\section{Perbandingan Average Trading Volume Activity Sebelum dan Sesudah Pemilihan Legislatif dan Pemilihan Presiden Tahun 2019}

. Hasil penelitian diatas menunjukkan bahwa hipotesis kedua (H2) yakni adanya beda average trading volume activity sebelum dan sesudah pileg dan pilpres 2019 yakni didukung. Sehingga skejadian pileg dan pilpres 2019 menunjukkan bahwa para pelaku target merespon secara positif terhadap pelaksanaan pileg dan pilpres 2019. Analis target modal sudah memprediksi sebelumnya menyusul rilis hasil hitung 
cepat (quick count) perolehan suara pileg dan pilpres 2019 oleh beberapa lembaga survei, diantara Saiful Mujani Riset \& Consulting (SMRC), Indikator, Cyrus Network dan Charta.

\section{Kesimpulan, Keterbatasan Dan Saran Kesimpulan}

1) Tidak ada perbedaan average abnormal pengmbalian sebelum/sesudah kejadian pemilihan legislatif dan pemilihan presiden tahun 2019, sehingga hipotesis 1 ditolak.

2) Ada perbedaan average trading volume activity sebelum/sesudah pemilihan legislatif dan pemilihan presiden tahun 2019, sehingga hipotesis 2 diterima.

\section{Keterbatasan Penelitian}

1) Penelitian ini tidak melakukan pengelompokkan saham (cluster) berdasarkan, sehingga penulis tidak dapat mengetahui perbandingan reaksi antara suatu sektor dengan sektor yang lain dengan adanya kejadian pileg dan pilpres 2019.

2) Belum adanya periode pengamatan yang ideal dalam suatu penelitian yang menggunakan metode event study. Dalam penelitian ini lamanya periode pengamatan hanya 10 hari bursa yaitu 5 hari bursa sebelum kejadian pileg dan pilpres 2019 dan 5 hari sesudah kejadian pileg dan pilpres 2019. Hal ini kemungkinan berpengaruh terhadap pengujian hipotesis yang dilakukan.

3) Penelitian selanjutnya dapat ditambah variabel lain karena masih banyak variabel lain seperti frekuensi perdagangan, jenis industri, ukuran perusahaan dan struktur kepunyaan saham yang juga dapat diteliti.

\section{Saran}

Adapun saran yang bisa peneliti berikan untuk perbaikan kedepannya yaitu:

1) Penelitian berikutnya menambah variabel penelitian supaya dapat meningkatkan validasi hasil penelitian.

2) Penelitian selanjutnya disarankan untuk melakukan pengelompokkan saham (cluster) berdasarkan reaksi antara suatu sektor dengan sektor yang lain

Bagi emiten, berdasarkan hasil penelitian ini disarankan untuk meningkatkan kualitas fundamental perusahaan untuk meminimalisir pergerakan nilai saham atau aktivitas, sehingga kejadian-kejadian tertentu seperti kejadian politik terlalu nilai saham emiten, dan nilai saham lebih dapat dikendalikan oleh emiten sendiri.

\section{Daftar Pustaka}

Arikunto, Suharsimi. 2012. Prosedur Penelitian (Suatu Pendekatan Praktik). Cetakan Keduabelas. Jakarta: Rineka Cipta.

Ary, Tatang Gumanti. 2011. Manajemen Investasi (Konsep, Teori dan Aplikasi). Jakarta: Mitra Wacana Media.

Bialkowski, Jedrzej., Katrin Gottschalk \& Tomasz Wisniewski. 2006. Stock Market Volatility around National Elections. Journal of Banking \& Finance, 32: 9-16.

Budiman, Agus. 2014. Analisis Perbandingan Average Abnormal Return dan Average Trading Volume Activity Sebelum dan Sesudah Peristiwa Pemilihan Umum Presiden Tahun 2009 dan 2014. Under Graduates thesis. Semarang: Universitas Negeri Semarang.

Bursa Efek Indonesia. Tanpa Tahun. Indeks Harga Saham. Melalui https://www.idx.co.id/produk/indeks/. Diakses 10 Mei 2019.

Bursa Efek Indonesia. 2019. Daftar Saham untuk Perhitungan Indeks LQ45 Periode Februari s.d. Juli 2019. Melalui https://www.idx.co.id/data-pasar/datasaham/indeks-saham/. Diakses 10 Mei 2019.

Chandra, Chan H., Njo Anastasia, \& Gesti Memarista. 2014. Perbedaan Average Abnormal Return, Average Trading Volume Activity Sebelum dan Sesudah Pemilu di Indonesia. Jurnal FINESTA, 2(1): 114-118. Surabaya: Universitas Kristen Petra.

Chandra, T. 2015. Impact of Indonesia's 2014 Presidential Election Towards Stock Priceso Indonesia Stock Exchange. International Journal of Business and Management, 10(7): 172-183. Pekanbaru: STIE Pelita Indonesia.

Darmadji, Tjiptono \& Hendy M. Fakhruddin. 2012. Pasar modal di Indonesia (Pendekatan Tanya Jawab). Jakarta: Salemba Empat.

Ghozali, Imam. 2013. Aplikasi Analisis Multivariate dengan Program IBM SPSS 23. Cetakan VIII. Semarang: Badan Penerbit Universitas Diponegoro.

Hartono, Jogiyanto. 2015. Studi Peristiwa: Menguji Reaksi Pasar Modal Akibat Suatu Peristiwa. Edisi Pertama. Yogyakarta: BPFE. 
Hutami, Rizkia N. 2015. Abnormal Return dan Trading Volume Activity Sebelum dan Setelah Pemilihan Presiden Secara Langsung 9 Juli 2014 (Studi Kasus Pada Saham Lq-45). Skripsi. Semarang: Universitas Diponegoro.

Iqbal, Muhammad. 2019. Ada 16 Parpol Nasional Peserta Pemilu 2019, Tahu Apa Saja? Melalui https://kumparan.com/@kumparannews/ada16-parpol-nasional-peserta-pemilu-2019tahu-apa-saja. Diakses 25 April 2019.

Imelda., Hermanto \& Lukytawati. 2014. Abnormal Returns and Trading Volume in the Indonesian Stock Market in Relation to the Presidential Elections in 2004, 2009, and 2014. International Journal of Administrative Science \& Organization, 21(2): 65-76. Bogor: Institut Pertanian Bogor.

Lehander, Sofia \& Frida Lonnqvist. 2011. Parliementary Elections' Impact on Stock Returns. Stockholm: Stockholm School of Economics.

Luhur, Suryo. 2010. Reaksi Pasar Modal Indonesia Seputar Pemilihan Umum 8 Juli 2009 pada saham LQ-45. Jurnal Keuangan dan Perbankan, 14(2): 249-262. Yogyakarta: UPN Veteran Yogyakarta.

Martalena \& Malinda. 2011. Pengantar Pasar Modal. Edisi Pertama. Yogyakarta: Andi

Meidawati, Neni \& Mahendra Harimawan. 2004. Pengaruh Pemilihan Umum Legislatif Indonesia Tahun 2004 Terhadap Return Saham Dan Volume Perdagangan Saham LQ-45 Di PT. Bursa Efek Jakarta (BEJ). SINERGI, 7(1): 89-101. Semarang: Universitas Diponegoro.

Munawarah. 2009. Analisis Perbandingan Abnormal Return dan Trading Volume Activity Sebelum dan Setelah Suspend BEI. Tesis. Semarang: Universitas Diponegoro.

Rahmawaty \& Riezky R. Putri. 2015. The Impact of Indonesia Presidential Election Year 2014 on Abnormal Return and Trading Volume Activities of Stocks in Indonesia Stock Exchange (Event Study on Advertising Printing Media Stocks Listed on IDX). The 5th Annual International Conference, 9-11 September 2015. Banda Aceh: Universitas Syiah Kuala.

Ridwansah, Dery. 2019. Efek Pilpres 2019, IHSG Selama Sepekan Menguat 1,58 Persen. Melalui https://www.jawapos.com/ekonomi/finance/1 9/04/2019/efek-pilpres-2019-ihsg-selamasepekan-menguat-158-persen/. Diakses 25 April 2019

Samsul, Mohamad. 2015. Pasar Modal \& Manajemen Portofolio. Edisi Dua. Jakarta: Penerbit Erlangga.

Sekaran, Uma. 2006. Metodologi Penelitian untuk Bisnis. Buku 2. Edisi 4. Jakarta: Salemba Empat.

Sugiyono. 2013. Statistika Untuk Penelitian. Edisi 1. Bandung: Alfabeta.

Wiratmaja, Alit. 2019. Sukseskan Pemilu Serentak 2019.

Melalui http://rri.co.id/post/editorial/1421/editorial/su kseskan_pemilu_serentak_2019.html. Diakses 25 April 2019.

Wismar'ein, Dian. 2004. Reaksi Pasar atas Pengumuman Right Issue terhadap Abnormal Return Saham dan Likuiditas Saham. Tesis. Semarang: Magister Manajemen Universitas Diponegoro. 